\title{
Trees Outside Forest: Carbon Stock and Socio-economic Contribution
}

\author{
Bobby Thapa ${ }^{*}$, Sandesh Bolakhe, Basudev Pokhrel \\ Faculty of Forestry, Agriculture and Forestry University, Hetauda, Nepal \\ Email address: \\ bob.bee204@gmail.com (B. Thapa) \\ ${ }^{*}$ Corresponding author
}

\section{To cite this article:}

Bobby Thapa, Sandesh Bolakhe, Basudev Pokhrel. Trees Outside Forest: Carbon Stock and Socio-economic Contribution. American Journal of Environmental and Resource Economics. Vol. 6, No. 1, 2021, pp. 16-22. doi: 10.11648/j.ajere.20210601.13

Received: September 9, 2019; Accepted: October 5, 2019; Published: March 17, 2021

\begin{abstract}
Trees Outside Forest (TOF) are considered important from an environmental, economic and social perspective. Due to its spatial heterogeneity and distribution patterns, the assessment of TOF and its importance is largely absent. The current study was carried out to assess the major TOFs, carbon stocks contained and socio-economic contribution of TOFs in Banepa Municipality. A stratified random sampling method was used for the collection of data (i.e. agriculture land, settlement area and other than agriculture and settlement). Circular plots of $1,000 \mathrm{~m}^{2}$ having a radius of $17.84 \mathrm{~m}$ were laid out randomly in all three strata. A questionnaire survey and field observation was done to explore the socio-economic contribution of TOF. During the study, a total of 28 tree species were recorded. Socio-economic contribution of TOF were converted and presented in terms of monetary value per household per year (NRs/hh/yr), i.e. firewood ( $960 \mathrm{NRs} / \mathrm{hh} / \mathrm{yr})$, fruits $(820 \mathrm{NRs} / \mathrm{hh} / \mathrm{yr})$, selling whole tree (5500 NRs/hh/yr), timber (25500 NRs/hh/yr) and fodder (4543 NRs/hh/yr). About 23\% of the TOF are mostly used for fodder collection and the other $23 \%$ of TOF for fruit collection. The total carbon stock was calculated to be 5.76 ton/ha (1.39ton/ha in agriculture land, 2.09ton/ha in the settlement area, and 2.27 ton/ha in other than agriculture or settlement) in the study area and the average carbon stock was calculated to be 1.92 ton/ha. Species-wise carbon stock was calculated where Prunus cerasoides and Alnus nepalensis were found to have a higher contribution in carbon storage. Hence, there is a visible impact of TOF in carbon storage and socio-economic improvement of local people.
\end{abstract}

Keywords: Biomass, Carbon Stock, Trees Outside Forest

\section{Introduction}

Trees outside forest (TOF) includes all trees that exist beyond the forest and other wooded lands [1]. It includes agroforestry systems, orchards, small clumps of trees, permanent meadows and pastures, trees growing on farms and in urban and per urban zones, in lines along rivers, canals and roads, and in gardens, parks and towns [2]. "Trees outside forest may be productive; such as orchards, and trees in fields and other agroforestry systems, or protective; such as trees with an ecological or landscaping function; or ornamental; such as trees around houses, and in parks and towns." TOF can be found in all climates, land types, land uses, and regions and have important economic, social, and environmental implications on local, national, and global scales [3]. Therefore, this study attempts to investigate the floristic composition of TOF and to assess socioeconomic benefits from TOF. Although the contribution of the tree outside forest has been appreciated, little is known about the resource itself [4].

TOF is a good source of financial support for the rural household economy, through food, fuel, fodder, employment and income. TOF and especially agroforestry offer a range of ecological, economic, social and religious functions. The contribution of TOF has a high potential for livelihood improvement. In India, $25.6 \%$ of the national growing stock was found outside of forests and in some Indian states, even the majority of wood supplies come from non-forest trees [5].

Over the last decades, decision-makers have become increasingly aware of the importance of TOF, and as a consequence, this tree resource is, nowadays, often considered in forest monitoring systems [6]. As forest products from the natural forest are increasingly less available for various environmental and other reasons, TOF is playing numerous and essential roles and functions.

Tree growing practices in and around homesteads, and on farmland have long been associated in rural areas of Nepal, and hence, considered as integral components of rural livelihoods [7]. A detailed assessment of the dynamics of 
carbon (C) stocks in China's TOF is necessary for fully evaluating the role of the country's trees in the national $\mathrm{C}$ cycle [8]. Trees on farms have been recognized that it protects soil, water and biological diversity, provide shelter and shade for the local people. At the same time, it contributes to climate change mitigation through carbon sequestration [9]. TOF are important in providing fuelwood, food, small timber, firewood and other products of domestic consumption. The role of TOF can be seen in different fields like environment, agriculture, livelihood, greenhouse gas effect, agroforestry, etc. The findings of this research were the role of TOF such as carbon stock, socio-economic contribution and its uses in the study area.

\section{Materials and Methods}

\subsection{Study Area}

Kavrepalanchowk is one of the seventy-seven districts of Nepal located in Province 3. It lies in $27^{\circ} 37^{\prime}$ north to $27^{\circ} 617^{\prime}$ longitude and $85^{\circ} 33^{\prime}$ to $85^{\circ} 55^{\prime}$ east latitude. Banepa is a municipality situated at about $4,800 \mathrm{ft}$. $(1,500 \mathrm{~m})$ above sea level in this district. At the time of the 2011 Nepal census, it has a population of 24,764. Banepa's climate is classified as warm and temperate. In winter, there is much less rainfall than in summer. The average annual temperature is $17.2^{\circ} \mathrm{C}$ and about $1745 \mathrm{~mm}$ of precipitation falls annually. Newars are the predominant ethnic group, while Brahmins, Chettris, Janajatis and Dalits constitute the other major ethnic groups. Most of the households of the area are engaged in farming activity and business, while others are engaged as wage labor and in-service/job. Currently, the area is having partly conserved Schima wallichii forest, mixed broad-leaved forest and newly established Alnus nepalensis woodlands. This research focuses on TOF of ward no. 5 of this municipality. This ward has a large number of TOF in agricultural lands, settlement areas, backyards, private gardens, parks, along streets, waterways, small isolated areas (less than $0.5 \mathrm{ha}$ ) and narrow lines. The local people of the area have been using the vegetation for various uses as a staple food (cereals), vegetables, timber, fodder, etc.

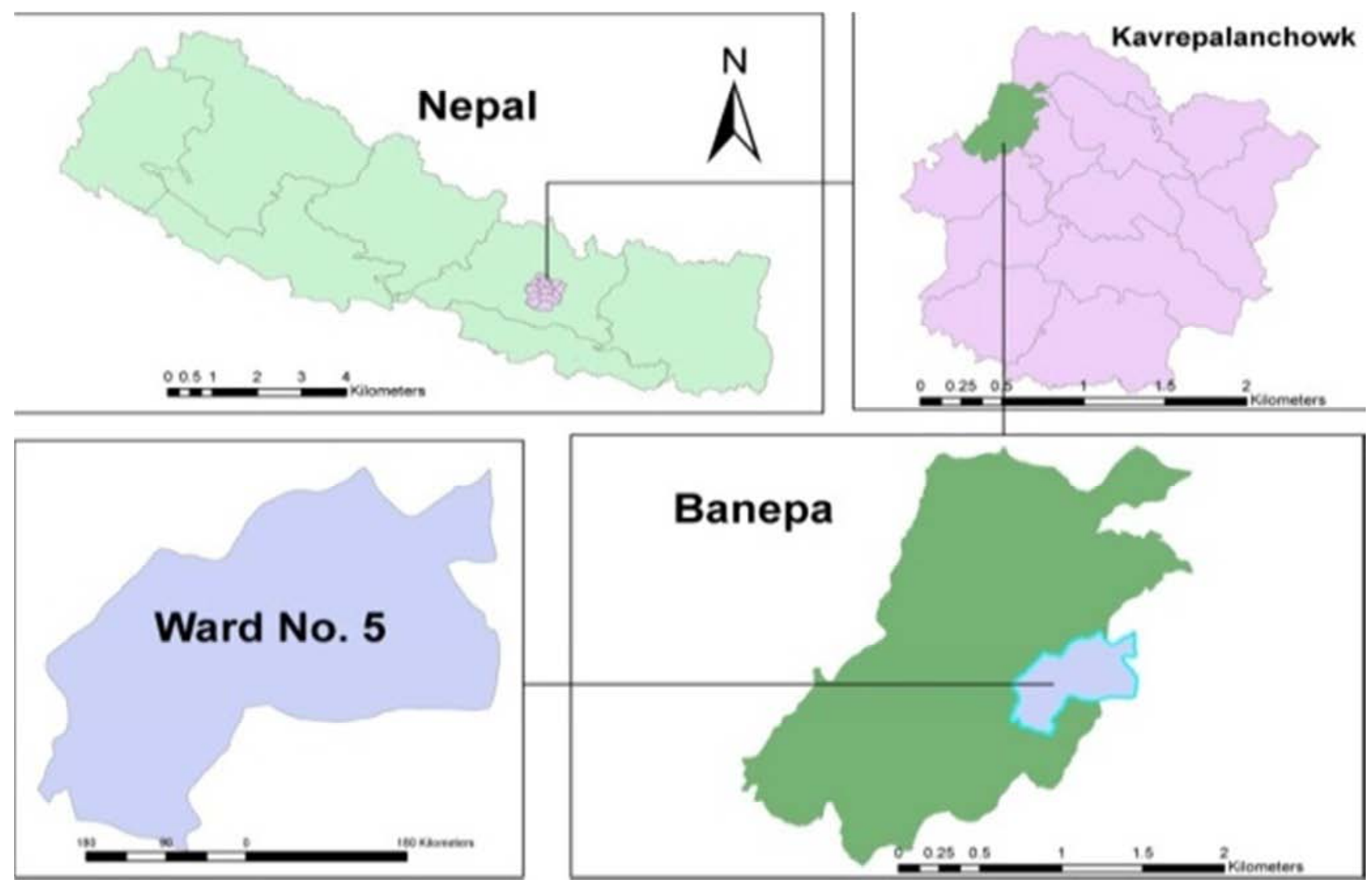

Figure 1. Map of the study area.

\subsection{Primary Data Collection}

Stratified random sampling was applied to collect data in the study area. The strata were laid following the TOF present in the area. In the study area three substrata i.e. TOF on agriculture, TOF on the settlement, and TOF on land not used for agriculture or settlement were considered. Sample plots were laid randomly in the study area in such a way that they represented the particular strata. Altogether 15 sample plots were laid randomly in the study area i.e. 5 sample plots representing each stratum. The plot size of $1,000 \mathrm{~m}^{2}(0.1 \mathrm{ha})$ in a circular shape having a radius of $17.84 \mathrm{~m}$ was laid out covering all three strata [10]. 


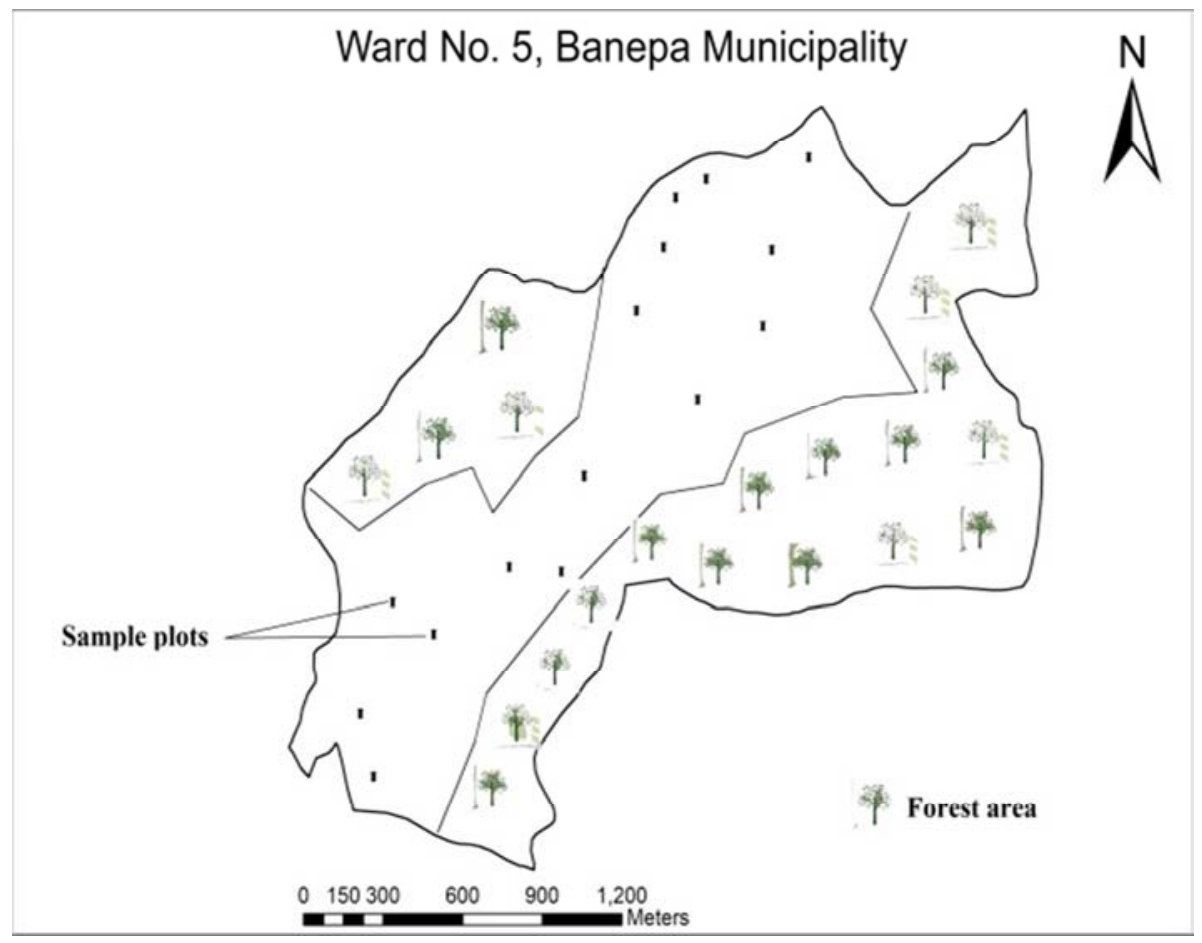

Figure 2. Location of sample plot in the study area.

Height and Diameter at Breast Height (DBH, 1.3m) of trees and poles within the sample plot were measured using range finder and diameter tape respectively and recorded in the tally sheet. The location of the sample plot was recorded using GPS. The local name of the trees and poles was noted.

To collect the socioeconomic data field observation and questionnaire survey was done. The main aim of the field observation was to record the details of the TOF seen during the visit. This method was used for observing different species within the study area. The name, condition and site of availability of TOF were also recorded. For the questionnaire survey, households were selected on a random basis situated near the sample plot areas. Altogether 30 households were surveyed. A questionnaire was asked to the selected households to record the demographic characteristics of respondents and the socio-economic contribution of TOF in the study area.

\subsection{Secondary Data Collection}

Existing works of literature were collected from the sources like a library, various government offices, journals, the internet, existing service providers and other sources recognized during the research period.

\subsection{Data Analysis}

Arc GIS 10.2.2 was used for map preparation. The data was processed and analyzed using computer software packages such as MS. Excel. The results were presented in text, tables and figures and interpreted accordingly.

Volume calculation

Field data such as local name, DBH and tree height was transferred into the database environment. To evaluate the growing stock (volume) of the TOF the following formula as recommended by DoF [11] was used.

$$
\text { Volume } \frac{\pi \times(\mathrm{DBH})^{2} \times \mathrm{h} \times f f}{4}
$$

Where $\pi=$ is $3.14, \mathrm{DBH}=$ Diameter at Breast Height $(\mathrm{cm})$, $\mathrm{h}=$ height of the tree $(\mathrm{m}), f f$ is the form factor that is 0.5 .

Biomass and carbon stock calculation

Above Ground Tree Biomass (AGTB): The logarithmic transformation of the algometric formula was used to estimate above-ground biomass. The total above-ground tree biomass was calculated using the equations developed by Chave et al [12].

$$
\text { AGTB }(\text { in } \mathrm{kg})=0.0509 \times \rho \mathrm{D}^{2} \mathrm{~h} .
$$

Where $\rho$ is Dry wood Density $\left(\mathrm{g} / \mathrm{m}^{3}\right)$.

Where $0.47=$ Conversion factor or default carbon fraction). Then $47.5 \%$ carbon (IPCC default value) in the woody biomass was considered for carbon content estimations.

Above ground carbon content $=0.475 \times$ AGTB

Below Ground Biomass (BGB): The following relationship as recommended by MacDicken [13] was used to estimate the root biomass.

Root biomass or BGB: $20 \%$ of AGTB

Below ground carbon content $=0.475 \times \mathrm{BGB}$

Total carbon=above ground carbon + below ground carbon.

\section{Results and Discussions}

\subsection{Tree Species of TOF in the Study Area}

Table 1 shows the name of different species of trees found in the sample plots during field inventory. There were a total of 18 tree species recorded in the tally sheet using sample plots during field inventory. Most of them are multipurpose species. Trees like Melia azedarach, Litsea monopetala, Prunus cerasoides are good fodder species. Alnus nepalensis 
and Pinus roxburghii are economically important species in the study area. Myrica esculenta, Choerospondias axilaris, Citrus sinensis, Pyrus pyrifolia are used for getting fruits. One of the exotic species found in the area is Shorea borneensis.

Table 1. Tree species recorded from field inventory.

\begin{tabular}{lll}
\hline S. N. & Local name & Botanical name \\
\hline 1. & Bakaino & Melia azedarach \\
2. & Chilauney & Schima wallichi \\
3. & Dudhilo & Ficus nemoralis \\
4. & Guras & Rhododendron arboretum \\
5. & Kafal & Myrica esculenta \\
6. & Kaiyo & Grevillea robusta \\
7. & Kapur & Cinnamommum camphora \\
8. & Kutmero & Litsea monopetala \\
9. & Lapsi & Choerospondias axilaris \\
10. & Malaysian sal & Shorea borneensis \\
11. & Orange & Citrus sinensis \\
12. & Paiyu & Prunus cerasoides \\
13. & Pear & Pyrus pyrifolia \\
14. & Pipal & Ficus religiosa \\
15. & Salla & Pinus roxburghii \\
16. & Saur & Betula alnoides \\
17. & Timilo & Ficus racemosa \\
18. & Uttis & Alnus nepalensis \\
\hline
\end{tabular}

Table 2. Tree species recorded from questionnaire survey.

\begin{tabular}{lll}
\hline S. N. & Local name & Scientific name \\
\hline 1. & Aalupakhada & Prunus cerasifera \\
2. & Aamba & Psidium guajava \\
3. & Badhar & Artocarpus lacucha \\
4. & Bakaino & Melia azedarach \\
5. & Chap & Mechelia champaca \\
6. & Chilauney & Schima wallichi \\
7. & Kaiyo & Grevillea robusta \\
8. & Katus & Castonopsis indica \\
9. & Khurpani & Prunus armeniaca \\
10. & Kimbu & Morus alba \\
11. & Kutmero & Litsea monopetala \\
12. & Lapsi & Choerospondias axilaris \\
13. & Lemon & Citrus limon \\
14. & Mahuwa & Madhuca longifolia \\
15. & Malasiyan sal & Shorea borneensis \\
16. & Mango & Magnifera indica \\
17. & Okhar & Juglans regia \\
18. & Orange & Citrus sinensis \\
19. & Paiyu & Prunus cerasoides \\
20. & Parijat & Nyctanthes arbor-tristis \\
21. & Pear & Pyrus pyrifolia \\
22. & Phalat & Quercus oxydon \\
23. & Pipal & Ficus religiosa \\
24. & Saur & Betula alnoides \\
25. & Simal & Bombax ceiba \\
26. & Salla & Pinus roxburghii \\
27. & Tooni & Cedrela toona \\
28. & Uttis & Alnus nepalensis \\
\hline & &
\end{tabular}

Table 2 shows name of different species of tree listed during questionnaire survey. A total of 28 species of trees were recorded during questionnaire survey. Most of them are multipurpose species. Melia azedarach, Litsea monopetala,
Prunus cerasoides are good fodder species. Alnus nepalensis and Pinus roxburghii are economically important species recorded in the study area. Prunus cerasifera, Psidium guajava, Morus alba, Castonopsis indica. Choerospondias axilaris, Magnifera indica, Citrus sinensis, Pyrus pyrifolia are used for getting fruits. One of the exotic species found in the area was Shorea borneensis. Species like Ficus religiosa, Mechelia champaca are used for different religious purpose.

\subsection{Socio-economic Characteristics of the Study Area}

The study area has a total area of 3.99 sq. $\mathrm{km}$ with a total population of 5336. Among the total population, there were altogether 2516 male and 2820 female in the study area. The gender composition is shown in the graph below.

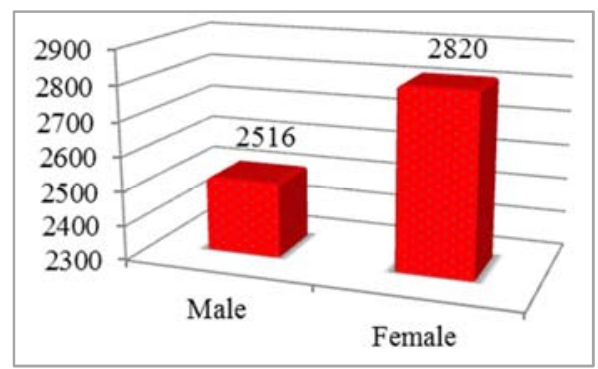

Figure 3. Gender Composition of the study area.

The economic status of the respondents is represented by the graph below. The economic status was classified into poor and very poor as there were no rich households in the study area. Among the total of 30 households surveyed, 13 of them were poor and 17 of them were very poor.

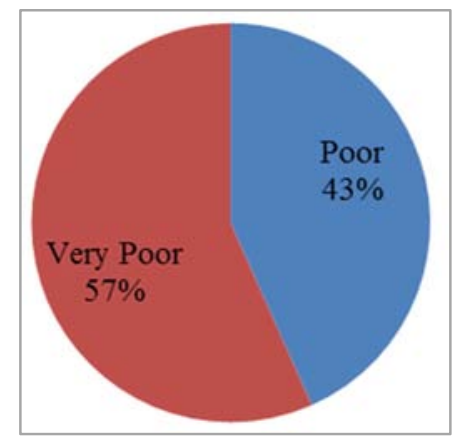

Figure 4. Economic status of the respondents.

\subsection{Contribution by TOF in the Study Area}

Especially TOF has a very direct relation with the people's daily activities and their health. In the study area, maximum respondents have preferred TOF for collecting the tree products rather than Community Forest or any other sources like market, factories, furniture etc. The main reason behind this was the presence of TOF in their agricultural land and in areas near houses. It was both cost effective and time effective.

Table 3. Different sources of tree products and their preference percentage.

\begin{tabular}{ll}
\hline Sources of tree products & Preference (\%) \\
\hline TOF & $65 \%$ \\
Community Forest & $26 \%$ \\
Other sources & $9 \%$ \\
\hline
\end{tabular}




\subsubsection{Uses of TOF}

Table 4. Different uses of TOF in the study area.

\begin{tabular}{ll}
\hline Uses of TOF & Percentage \\
\hline Fodder & $23 \%$ \\
Fruits & $23 \%$ \\
Furniture & $20 \%$ \\
Firewood & $12 \%$ \\
Timber & $9 \%$ \\
Religious purpose & $5 \%$ \\
Medicine & $4 \%$ \\
Selling whole tree & $3 \%$ \\
Flower & $1 \%$ \\
\hline
\end{tabular}

TOF and its uses in the study area can be seen in table 4 where it is used mostly for the fodder collection i.e. $23 \%$ and fruits i.e. $23 \%$. Flower has only contributed $1 \%$ in overall use of TOF.

TOF is essential source of the wood and non-wood products crucial for people's day-to-day needs [2]. The findings of different uses of TOF in the study area have also supported the results of study done by FAO in 2002. Trees on farms protect soil, water and biological diversity, provide shelter and shade for the local people [9].

\subsubsection{Monetary Value of Uses of TOF}

Figure 5 shows the different uses of TOF which is converted in monetary value. The result is expressed as per household per year among the total respondents of the study area i.e. NRs. 37,323 per household per year. It is seen that timber use of TOF has highest value while fruits use of TOF with minimum monetary value.

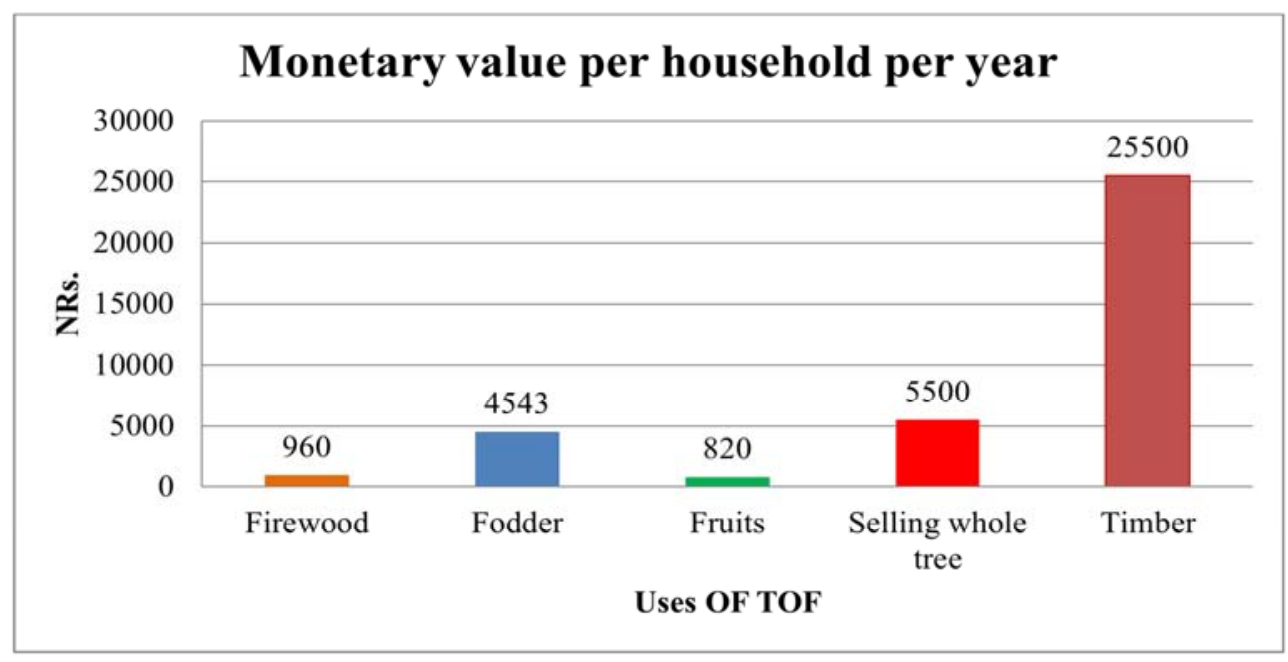

Figure 5. Monetary value of uses of TOF.

In Kerala State, India, TOF are the major source of local wood production, accounting for $90.1 \%$ of the timber production and meeting $89.2 \%$ of local fuelwood supply during the year 2000-2001 [14]. This study also shows that the supply of timber from TOF is highest than other uses. A similar type of study done by Regmi and Garforth [15] on the use of agroforestry systems in Chitwan district, Nepal reported that the contribution of TOF has a high potential for livelihood improvement of local people.

\subsection{Distribution of Growing Stock, Above Ground Tree Biomass and Carbon Stock}

Figure 6 has shown the growing stock, above-ground tree biomass and total carbon stock of TOF in each stratum. The reason behind the highest growing stock in OLtSoA (Other Land than Settlement or Agriculture) was the presence of TOF in good numbers as they are undisturbed in comparison to settlement area and agricultural land. A study carried out in Nawalparasi district of Nepal found that the trees outside forest contain $3.3 \mathrm{~m}^{3} /$ ha stem volume [16]. The average growing stock was calculated to be $5.17 \mathrm{~m}^{3} /$ ha in the study area which is near to the findings of the study done in Nawalparasi district. The study was done by Indian
Academic of Sciences in December, 2012 in southern Haryana reports that above-ground TOF biomass to be 1.26 tons/ha in the scattered trees [17]. In this study, the average above growing stock was calculated to be 3.36 tons/ha. The reason behind high AGTB from this study in comparison to the study done by the Indian Academic of Sciences could be the inclusion of linear trees, trees in patches, etc. along with scattered trees.

Trees can help in sequestering carbon - in their live biomass [18]. Trees on farms are a sound strategy to sequester and store carbon in wood biomass [19]. Though people are getting benefits by favor of TOF in form of lumber, firewood, fruits honey and such products, little has been documented on their potential in carbon storage. It is believed that TOF contain more total wood biomass, hence large carbon stocks because more land is involved [20]. To support the above statements, the calculation in terms of carbon stock was done in this study. It has been seen that the carbon stock was varied in TOF [6] where this study also shows the variation of carbon stock in three strata of the study area which is directly related to the variation in AGBT in TOF of the study area. 


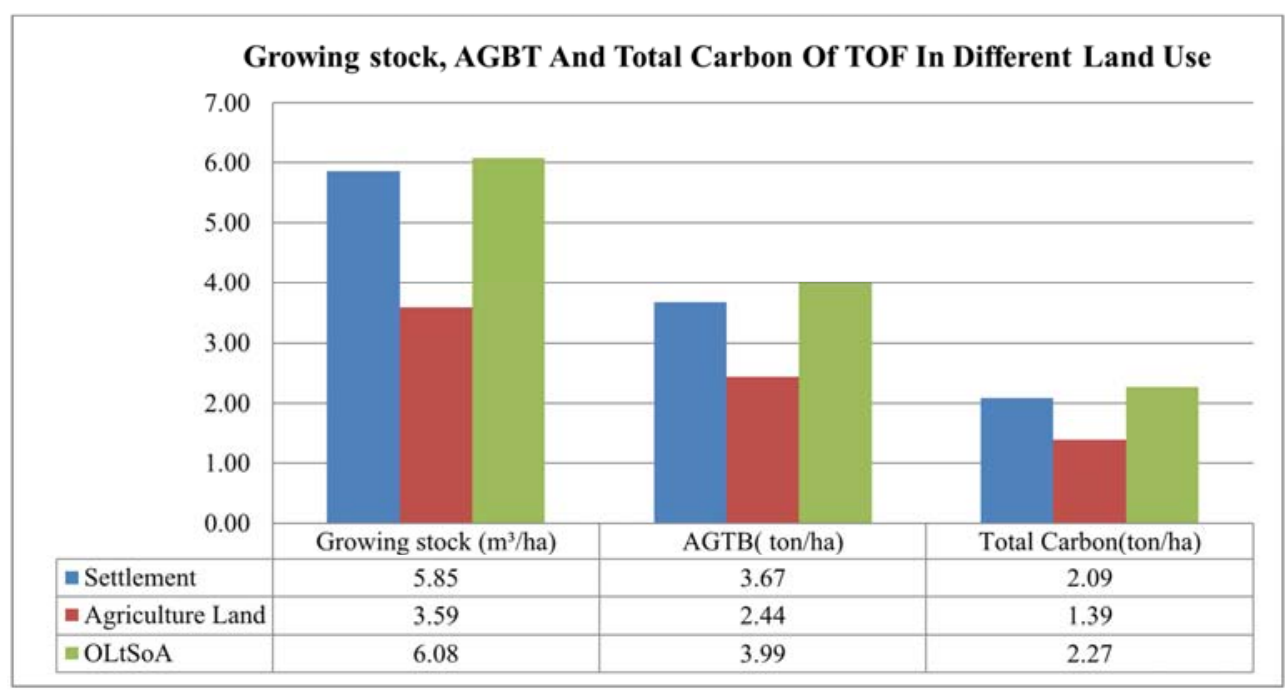

Figure 6. Distribution of growing stock, above-ground tree biomass and carbon stock in different strata.

\subsection{Distribution of Carbon Stock by Different Species in Different Strata}

Table 5. Distribution of carbon content in different strata by species.

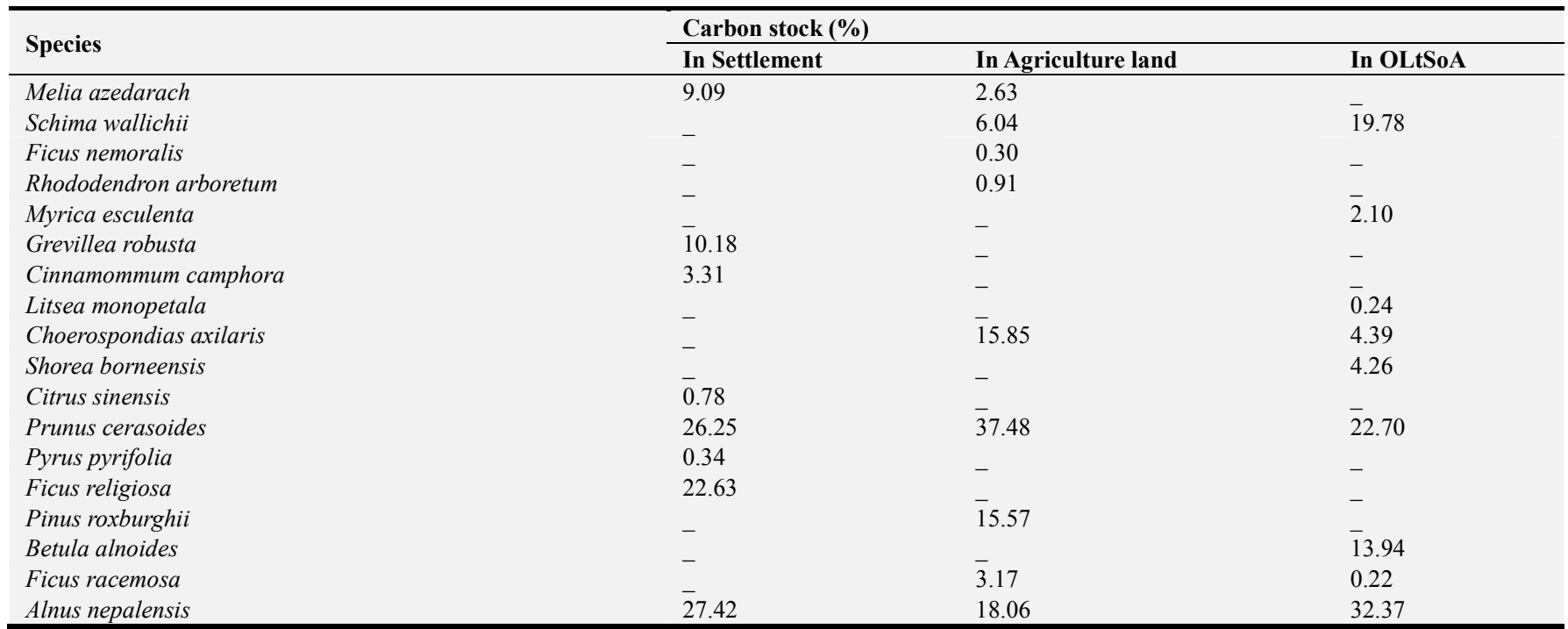

Table 5 shows Prunus cerasoides (26.25\%) and Alnus nepalensis $(27.42 \%)$ have higher contributions for carbon storage than other species. The main reason behind this can be their presence in a high number in the settlement area. Pyris pyrifolia $(0.34 \%)$ has the least contribution to carbon storage. Similarly, Prunus cerasoides (37.48\%) has a higher contribution for carbon storage than other species. The main reason behind this can be their presence in high number in the agriculture land. Ficus nemoralis $(0.30 \%)$ has the least contribution to carbon storage. In OLtSoA Alnus nepalensis $(32.37 \%)$ have a higher contribution for carbon storage than other species. The main reason behind this can be their presence in high numbers. Ficus racemosa $(0.22 \%)$ and Litsea monopetala $(0.24 \%)$ has the least contribution for carbon storage.

\section{Conclusions}

The study shows a higher amount of growing stock, biomass and carbon stock in land use other than agriculture and settlement followed by settlement and agricultural land. This could be attributed to the non-disturbance of such land areas to maintain ecological balance. In the case of settlement areas, trees were cut for construction and developmental works while agricultural land contains few trees and more crops. The average carbon stock of the three strata was found to be 1.92 ton/ha in the study area. Trees on farms have a visible impact on the socio-economic upliftment of local people in the study area. Socioeconomic importance was converted into total monetary value where NRs. of 37,323 per household per year was annually contributed by TOF for livelihood improvement of local people. TOF have the potentiality for biodiversity conservation and carbon trade.

The foremost thing is the robust monitoring of TOF across the nation is necessary. TOF can prove one of the best mediums to fight present problems like forest deforestation and degradation, climate change and pollution. Thus, this research can help to give an overview and understand the essentials of TOF to people involved in the natural resource management sector. The Government of 
Nepal should incorporate the proper program to understand the ecological and social dimensions of TOF at the grass-root level. Furthermore, the result gained from this research will assist the forest experts, resource managers and community people in understanding the importance of TOF and help them to apply the proper management techniques. The involvement of people in the sustainable utilization of TOF can help them to become a better steward of a healthy and viable environment that provides diverse human benefits and will contribute to the national economy. Consequently, at a higher level, separate policies, laws and acts on TOF are necessary and TOF management plans should be formulated. Therefore, it is recommended to carry out similar types of study in other areas and aware people of the sustainable use of TOF so that it continues to store carbon and contribute socio-economically.

\section{Acknowledgements}

We would like to express our deepest appreciation to the Faculty of Forestry, Agriculture and Forestry University for this research opportunity and financial support and sincere gratitude to all the helping hands.

\section{References}

[1] FAO (2001). Trees Outside Forests, A Key Factor in Integrated Urban and Rural Management.

[2] FAO (2002). Tree Outside Forests: Towards a better awareness.

[3] de Foresta, H., Somarriba, E., Temu, A., Boulanger, D., Feuilly, H. \& Gauthier, M. (2013). Towards the Assessment of Trees Outside Forests. FAO Resources Assessment Working Paper no. 183, Rome, Italy.

[4] FAO (2006). Global Forest Resources Assessment (2005). Progress towards sustainable Forest Management. FAO Forestry Paper 147. Food and Agriculture Organization of the United Nations, Rome, Italy.

[5] Ahmed, P. (2008). Trees outside forests (TOF): a case study of wood production and consumption in Haryana. International Forestry Review, 10, pp. 165-172.

[6] Yadav, Y., Bahadur, B., Chhetri, B., Raymajhi, S., Rajtiwari, K \& Sitaula, B. K. (2017). Importance of trees outside forest (TOF) in Nepal: a review. Octa Journal of Environmental Research, 5 (2): 70-81. 5. 70-81.

[7] Oli, B. N. (2002). Trees outside forests: an ignored dimension of forest resource assessment. Banko Janakari 12 (1): 79- 81.
[8] Guo, Z. D., Hu, H. F., Pan, Y. D., Birdsey, R. A. \& Fang, J. Y. (2014). Increasing biomass carbon stocks in trees outside forests in China over the last three decades, Biogeosciences, 11, 4115-4122, https://doi.org/10.5194/bg-11-4115-2014.

[9] Baral, S. K., Malla, R., Khanal, S. \& Shakya, R. (2013). Trees on farms: diversity, carbon pool and contribution to rural livelihoods in Kanchanpur District of Nepal. Banko Janakari. 23. 10.3126/banko.v23i1.9462.

[10] ITTO (2012). The Inventory and Monitoring of Tree Resources Outside Forest in Thailand.

[11] DoF (2003). Community Forestry Inventory Guideline. Community Forests Division, Department of Forests, Kathmandu, Nepal.

[12] Chave, J., Andalo, C., Brown, S., Cairns, M., Chambers, J., Eamus, D., Folster, H., Fromard, F., Higuchi, N., Kira, T., Lescure, J. P., Nelson, B., Ogawa, H., Puig, H., Riera, B. A. \& Yamakura, T. (2005). Tree allometry and improved estimation of carbon stocks and balance in tropical forests. Oecologia, $145,87-99$.

[13] MacDicken, K. G. (1997). A Guide to Monitoring Carbon Storage in Forestry and Agroforestry Projects, Arlington, USA, Winrock National Institute for Agricultural Development.

[14] Krishnankutty, C. N., Thampi, K. B., \& Chundamannil, M. (2008). Trees Outside Forests (TOF): A Case Study of the Wood ProductionConsumption Situation in Kerala, Int. Forest. Rev., 10, 156-164.

[15] Regmi, B. N. \& Garforth, C. (2010). Trees outside forests and rural livelihoods: a study of Chitwan District, Nepal. Agroforestry systems, 79 (3): 393-407.

[16] Kharal, D. K., Giri, R. K. \& Karna, D. L. (2008). Assessment of Trees Outside Forest: Nawalparasi District. Department of Forest Research and Survey, Kathamndu, Nepal.

[17] Singh, K. \& Chand, P. (2012). Above-ground tree outside forest (TOF) phytomass and carbon estimation in the semiarid region of southern Haryana: A synthesis approach of remote sensing and field data: pp. 1469-1482.

[18] Dogra, A. S. \& Chauhan S. K. (2016). Trees Outside Forests In India: Socio-Economic, Environmental and Policy Issues.

[19] Somarriba, E., Rocabado, G. C., Willan, C., Rolando, C., \& Ordonez, J. (2017). Trees on Farms for Livelihoods, Conservation of Biodiversity and Carbon Storage: Evidence from Nicaragua on This "Invisible" Resource. 10.1007/978-3319-69371-2 15 .

[20] Muriga, C. S., Malimbwi, R. E., Dr. \& Zahabu E. (2014). Carbon Storage Potential of Trees Outside Forests under Private and Communal Tenure Regimes in Ng'iresi Village, Arumeru District, Tanzania. 